\title{
MANAGEMENT OF FOOD ALLERGENS IN THE FOOD INDUSTRY*
}

\author{
Bogdan Pachołek $^{1 凶}$, Sylwia Sady ${ }^{1}$, Emilia Kupińska-Adamczyk
}

${ }^{1}$ Poznań University of Economics and Business, Poland

\begin{abstract}
Ensuring food safety for people suffering from various intolerances faces serious threats posed by allergens which have become a challenge for food manufacturers and mass caterers. These businesses are required to develop and implement appropriate programs to manage allergens present in their sites. The purpose of this paper was to analyze the actions taken by food manufacturers with respect to substances and products causing allergies or food intolerances in the context of providing consumers with a safe, properly labeled product. To achieve the objective of this study, a data analysis and synthesis method was employed based on requirements defined in obligatory and non-obligatory standards for food safety assurance and management in the food production sector. In summary, as regards allergen management, the companies must create appropriate conditions and take adequate measures (including the analysis of risks due to intentional and adventitious presence of allergens in food, and the implementation of appropriate preventive actions). Solutions provided in the mandatory standards, mainly GHP and HACCP, as well as in non-mandatory standards, such as ISO 22000, BRC, IFS and SQF, may be helpful in the management of substances causing allergies or intolerances.
\end{abstract}

Keywords: food allergens, food intolerance, allergens management, food safety assurance and management systems

\section{INTRODUCTION}

Food safety is an important part of the system for the protection of human health. The main objectives of the European Union's food safety policy include providing consumers with safe, high-quality food and with reliable, accurate and transparent information about food products. Every food company must ensure that food safety is not compromised, and has to provide accurate information on their offering so that the consumer can make a choice being well-informed.

Substances and products causing food allergies or intolerances are common, and are safe for most people. However, in case of food-sensitive consumers, such products may result in various dangerous and unpredictable symptoms. Therefore, it is extremely important for this vulnerable group to find and choose responsibly produced and accurately labeled food products. This has become a major challenge and obligation for food manufacturers because food allergens pose a real threat to human health and life.

\section{FOOD ALLERGENS: THREATS FOR THE FOOD INDUSTRY}

Nowadays, societies are suffering from growing number of health problems caused by allergic reactions.

*Publication costs were financed by Poznań University of Economics and Business.

\footnotetext{
$\bowtie$ PhD Eng Bogdan Pachołek, Poznań University of Economics and Business, Al. Niepodleglości 10, 61-875 Poznań, Poland, e-mail: bogdan.pacholek@ue.poznan.pl
} 
Allergens are commonly occurring substances which result in a number of undesirable symptoms experienced by a group of people with a genetically determined disturbance of $\mathrm{IgE}$ levels: cutaneous lesions; digestive, respiratory and cardiovascular reactions (e.g. urticaria, laryngeal edema, angioedema of lips, tongue or face; asthma; rhinitis; vomiting; diarrhea; hypotension; and life-threatening anaphylactic shocks) (Słowianek and Leszczyńska, 2011; Weng et al., 2016). These reactions include food allergies which have contributed to establishing a separate food manufacturing sector specifically targeted at those consumers.

Food allergy is defined as an adverse immune-mediated response which occurs reproducibly on exposure to a given food and is absent during its avoidance. While that food is generally not harmful to the population, it can affect personal eating habits of patients suffering from allergy (Górecka et al., 2013; Turnbull et al., 2015). According to data from the "Epidemiology of Allergic Disease in Poland" project, food allergies affect $13 \%$ of children aged $6-7,11 \%$ of children aged $13-14$ and $5 \%$ of adults (Samoliński et al., 2008). Almost $90 \%$ of all IgE-mediated food allergies (including anaphylaxis) are caused by the consumption of specific food ingredients and products, primarily including: milk, eggs, fish, crustaceans, nuts, peanuts, soybeans and wheat (Przybylski, 2016).

There are clear and hidden food allergens. The reason for the occurrence of the first group is the nature and composition of the food product. Hidden allergens, in turn, are neither ingredients nor components of the product; their presence is unintended or accidental. The identification of hidden allergens is usually based on the analysis of statements made by suppliers of raw materials, intermediate and finished products and all other production materials which include allergens, are used in the plant during various manufacturing processes and, as a result of cross-contamination, may potentially infiltrate the products (Dzwolak, 2015; Ukleja-Sokołowska and Bartuzi, 2015).

For most allergens, except for sulfur dioxide $(10 \mathrm{ppm})$ and gluten $(20 \mathrm{ppm})$, it is difficult to specify the acceptable consumption threshold which, if not exceeded, guarantees the absence (or a very low likelihood) of side effects experienced by allergy sufferers. Setting the thresholds is difficult because the phenomenon (and its importance in the dose-effect relationship) is highly unpredictable. Also, the detection and quantification tools currently used in the testing methods to assess the allergen content are subject to some constraints. However, attempts are made to determine safe levels for major allergens in food products using the available clinical data as a reference point. Zurzolo (2014) presented safe concentrations for 11 selected allergens based on data provided by The Allergen Bureau's VITAL (Voluntary Incidental Trace Allergen Labeling) Program, launched in 2007 in Australia and New Zealand (Table 1). The VITAL Program is a standardized allergen risk identification process for the food industry which allows the assessment of likely sources of allergen cross contact from raw materials and the processing environment, plus an

Table 1. Eliciting doses (ED) for common allergens causing allergies or intolerances

\begin{tabular}{lc}
\hline \multicolumn{1}{c}{$\begin{array}{c}\text { Substances or products causing allergies } \\
\text { or intolerances* }\end{array}$} & $\begin{array}{c}\text { Protein level } \\
(\mathrm{mg})\end{array}$ \\
\hline $\begin{array}{l}\text { Cereals containing gluten, namely: wheat, rye, } \\
\text { barley, oats, spelt, kamut and products thereof }\end{array}$ & 1 \\
$\begin{array}{l}\text { Crustaceans and products thereof } \\
\text { Eggs and products thereof }\end{array}$ & 1 \\
$\begin{array}{l}\text { Fish and products thereof } \\
\text { Peanuts and products thereof }\end{array}$ & 0.03 \\
$\begin{array}{l}\text { Soybeans and products thereof } \\
\text { Milk and products thereof (including lactose) }\end{array}$ & 0.1 \\
$\begin{array}{l}\text { Nuts, namely: almonds, hazelnuts, walnuts, } \\
\text { cashews, pecan nuts, Brazil nuts, pistachio nuts, } \\
\text { macadamia or Queensland nuts and products } \\
\text { thereof }\end{array}$ & 0.1 \\
$\begin{array}{l}\text { Celery and products thereof } \\
\text { Mustard and products thereof }\end{array}$ & 0.1 \\
$\begin{array}{l}\text { Sesame seeds products thereof } \\
\text { Sulfur dioxide and sulfites at concentrations of } \\
\text { more than } 10 \text { mg/kg } \\
\text { or } 10 \text { mg/l expressed as SO }{ }_{2}\end{array}$ & N/A \\
$\begin{array}{l}\text { Lupin and products thereof } \\
\text { Molluscs and products thereof }\end{array}$ & 0.05 \\
\hline
\end{tabular}

* Substances or products causing allergies or intolerances based on Regulation (EU) 1169/2011 of the European Parliament and of the Council of October 25, 2011.

Source: Allen et al., 2014; Ukleja-Sokołowska and Bartuzi, 2015; Zurzolo, 2014. 
evaluation of the amount present (Ukleja-Sokołowska and Bartuzi, 2015).

The enzyme-linked immunosorbent assay (ELISA) is the method most commonly used in laboratory analyses to detect and quantify substances which cause allergies or intolerances. Is it employed for quantitative detection of specific proteins in substances or products causing allergies in foodstuffs using polyclonal or monoclonal antibodies conjugated to a specific enzyme. Other currently developed detection tests include: LFA (lateral flow immunochromatographic assay), biosensors, and PCR-based DNA analyses. Most food processing plants rely on quick test strips to detect allergens in food. This is an easy and effective method for detecting trace amounts of allergens in food products.

The European Union established the RASFF (Rapid Alert System for Food and Feed) which operates under the supervision of the European Commission and is an important part of risk assessment for food and feed products. It provides an effective framework for the exchange of information between EU Member States on identified risks in food and feed and on the nature of activities undertaken, including those related to allergens. In the RASFF reports from recent years, allergens are the third most frequently notified threat category on the EU internal market, following pathogenic microorganisms and heavy metals. The 2015, 2016 and 2017 RASFF reports include 114, 86 and 116 notifications for allergens, respectively.

\section{LABELING OF FOOD ALLERGENS}

The scale of the problem and the possible consequences of the consumption of food allergens contained in food products resulted in the adoption of legal regulations on labeling of allergens in food in order to protect consumer safety. For the consumers, the main source of information about the presence of allergens in food is adequate product labeling. The obligation to declare the presence of allergens is applicable only to ingredients intentionally included in a food product. Currently, the list of required declarations of the presence of substances or products causing allergies or intolerances includes 14 products, as listed in Table 1 (Annex II to Regulation (EU) 1169/2011 of the European Parliament and of the Council). The European Commission, in order to provide consumers with reliable information, considering the latest scientific and technical knowledge, systematically analyzes and, if necessary, updates the list of substances or products causing allergies or intolerances by adopting delegated acts. Regulation (EU) 1169/2011 also obliges food manufacturers to label allergens present in both packaged and unpackaged products (marketed in bulk or served in restaurants and bars). As stated in the Regulation, the name of the substance or product causing allergy or intolerance must be emphasized through a typeset that clearly distinguishes it from the rest of ingredients list, for example by means of the font, style or background color.

Legal regulations applicable to food do not provide precise requirements on how to label hidden allergens that may potentially cross-contaminate the products. The unintended presence of allergens in the final product may result, for instance, from improper washing and preparation of the production line used for various foods (both containing and free from allergens). The manufacturers, made responsible for providing consumers with reliable product information, expect regulations to clearly set the minimum number of allergens which allows the product to be considered allergen-free. Furthermore, the regulations fail to define the "trace amount" of an allergen. More and more people suffer from allergies or intolerances to various food products or substances, and allergic reactions may be caused even by extremely low concentrations of allergens. Therefore, to address the needs of the consumers, food manufacturers more and more often extend their food labels with "may contain..." or "possible presence of..." warnings referring to specific hidden allergens named in Regulation (EU) 1169/2011. However, manufacturers should avoid overusing this wording with respect to all food products, as it may mislead the consumers.

\section{MANAGEMENT OF FOOD ALLERGENS IN THE FOOD PRODUCTION INDUSTRY}

Even trace amounts of allergens in products may pose a risk to consumer health. Therefore, food manufacturers are increasingly focusing on production methods that minimize or completely eliminate the use of allergenic substances. Food manufacturers and mass caterers are solely responsible for making statements on the absence of allergens in food ingredients and for assuring that no cross-contamination with allergens occurs during the production process. Such food products can be labeled with special symbols (e.g. Crossed Grain symbol for 
gluten-free products) or words (e.g. "Lactose-free" for non-lactose products) to indicate that the consumer may enjoy allergen-free food.

The primary sources of allergens in the food industry are product ingredients (product recipe items) and accidental cross-contamination from production and warehouse facilities, reusable equipment, employees, technological and packaging processes, cleaning and disinfection activities. One of the key elements in ensuring food safety is to effectively assess the risk of food allergen contamination at each stage of food production, considering all ingredients, additives, employees, workwear, machinery and equipment, finished products, packaging, by-products, waste, air, vehicles and the risk of cross-contamination.

Mandatory systems which must be implemented by manufacturers in order to ensure food safety include: Good Manufacturing Practice (GMP), Good Hygiene Practice (GHP) and Hazard Analysis and Critical Control Points (HACCP). The allergen risk analysis (which involves biological, physical and chemical factors and food production conditions that may cause a potential threat for consumer health) should extend to all areas of the facility and to all stages of the technological process where the allergens may occur. The description and intended purpose of the product should specify the target group of consumers and the group who should avoid the product because of allergy-related issues. Separate production lines should be used for food intended for allergy sufferers to minimize the risk of contamination of final products. Moreover, it is necessary to develop appropriate and effective cleaning and disinfection measures. The packaging and labeling processes are also crucial as the manufacturer has to implement procedures that prevent improper packing and labeling of final products. The employees should strictly adhere to all implemented food safety procedures because even trace amounts of allergens may result in contaminations with severe consequences. On the other hand, employers should make efforts to raise employee awareness through regular trainings. The required level of food safety may be achieved by implementing effective allergen management measures.

Allergen management in food plants is based on identifying all allergens present in the production area; defining their location and position in the process; identifying the products which contain specific food allergens and allergen-free products; assessing the risk of unintended presence of allergens in the product; and providing consumers with information on allergen-containing products. Because of implemented quality and food safety standards, manufacturers undertake surveillance of allergens present in the plant. This involves developing and implementing procedures which define critical checkpoints and methods for allergen elimination. As a consequence, the risk of unintended contamination of products with allergens which generally are not an ingredient thereof is minimized to an acceptable level, thus reducing the need for cautionary food labeling.

The first step of allergen control is to identify all raw materials and additives used in the plant which are, or may contain, allergens. Then, such items are adequately marked and separated. Depending on the nature of allergens, further segregation and mutual isolation may be required to minimize the risk of cross-contamination. Staff, and their awareness of threats associated with allergens, is an important aspect of allergen control. Therefore, systematic employees trainings reinforce their knowledge and self-discipline in complying with implemented principles.

Seconded personnel, specially marked equipment, and spatial isolation of stored raw materials, additives and processing aids are the measures used to prevent allergen cross-contamination. Moreover, production workers are forbidden to bring their own food products as it could become the source of new allergens in the plant. The next stage of control is the manufacturing process which starts with deliberate production planning (based on allergen content in various products) and determining the production sequence. Implementing these principles in practice involves the need to change the production sequence so as to start with allergen-free products and move to allergen-containing products arranged by increasing number of allergens. This requires the allergens not only to be effectively separated from non-allergens, but also to be used in the production process at predefined time intervals so as to prevent cross-contamination. Each group of products is manufactured on a separate production line and is then placed in separate, properly labeled containers. Packaging and adequate labeling of food products are crucial aspects of allergen management. A shrink-wrapped finished product guarantees the delivery of safe, allergen-free food.

In addition to adherence to applicable procedures, allergen management requires maintaining good hygiene of the production environment. In this regard, priority is given to compliance with GHP principles, validated 
methods for cleaning and disinfection of production facilities, machinery, devices and equipment. It is also important to periodically inspect allergen residues upon completing the production line cleaning process.

Unfortunately, some food manufacturers may experience multiple difficulties when establishing an allergen management policy. Solutions described in noncompulsory standards, including ISO 22000, BRC, IFS and SQF, provide some guidance for developing and implementing onsite management procedures for substances or products causing allergies or intolerances. Detailed requirements of each system are presented in Table 2. In the case of the BRC standard, "Management of allergens" is a major requirement of essential importance for the adoption and implementation of food quality and safety measures.

Table 2. Detailed requirements for allergen management, as provided for in the standards for quality and food safety management systems

\begin{tabular}{|c|c|}
\hline Standard & Chapter and characteristics of the requirements \\
\hline 1 & 2 \\
\hline ISO 22000:2005 & $\begin{array}{l}\text { Intended use } \\
\text { Groups of users for each product including consumer groups known to be especially vulnerable to spe } \\
\text { cific food safety hazards (e.g. allergens) shall be identified. }\end{array}$ \\
\hline ISO/TS & Allergen management \\
\hline 22002-1:2009 & $\begin{array}{l}\text { Allergens present in the product, either by design or by potential manufacturing cross-contact, shall } \\
\text { be declared by the manufacturer. Products shall be protected from unintended allergen cross-contact } \\
\text { by cleaning and line change-over practices and/or product sequencing. } \\
\text { Employees handling food should receive specific trainings in allergen awareness; allergen verification } \\
\text { procedures should be implemented. }\end{array}$ \\
\hline
\end{tabular}

$\mathrm{BRC}$

(Issue 7, 2015)

\section{Prerequisite programs}

The site shall establish and maintain programs necessary to create an environment suitable to produce safe and legal food products (e.g. allergen controls).

Describe the product

A full description for each product shall be developed, including information about allergens.

Identify intended use

Defining the consumer target groups, including the suitability of the product for vulnerable groups of the population (e.g. allergy sufferers).

Supplier and raw material approval and performance monitoring The company shall undertake a documented risk assessment of each raw material or group of raw materials including packaging to identify potential risks to product safety, legality and quality. This shall take into account potential allergen contamination.

\section{Maintenance}

Materials used for equipment and plant maintenance which pose a risk by direct or indirect contact with raw materials, intermediate and finished products, shall be food grade and of a known allergen status.

Staff facilities

Catering facilities shall be suitably controlled to prevent contamination of products

(e.g. as a source of introduction of allergenic material to the site).

Housekeeping and hygiene

As a minimum for food contact surfaces, equipment and for environmental cleaning in high-risk areas, limits of acceptable and unacceptable cleaning performance shall be defined (e.g. based on risk of allergen contamination).

Storage facilities

Documented procedures to maintain product safety and quality during storage shall be developed and implemented including segregation of products where necessary to avoid allergen cross-contamination. 
Table 2 - cont.

\begin{tabular}{|c|c|}
\hline 1 & 2 \\
\hline & 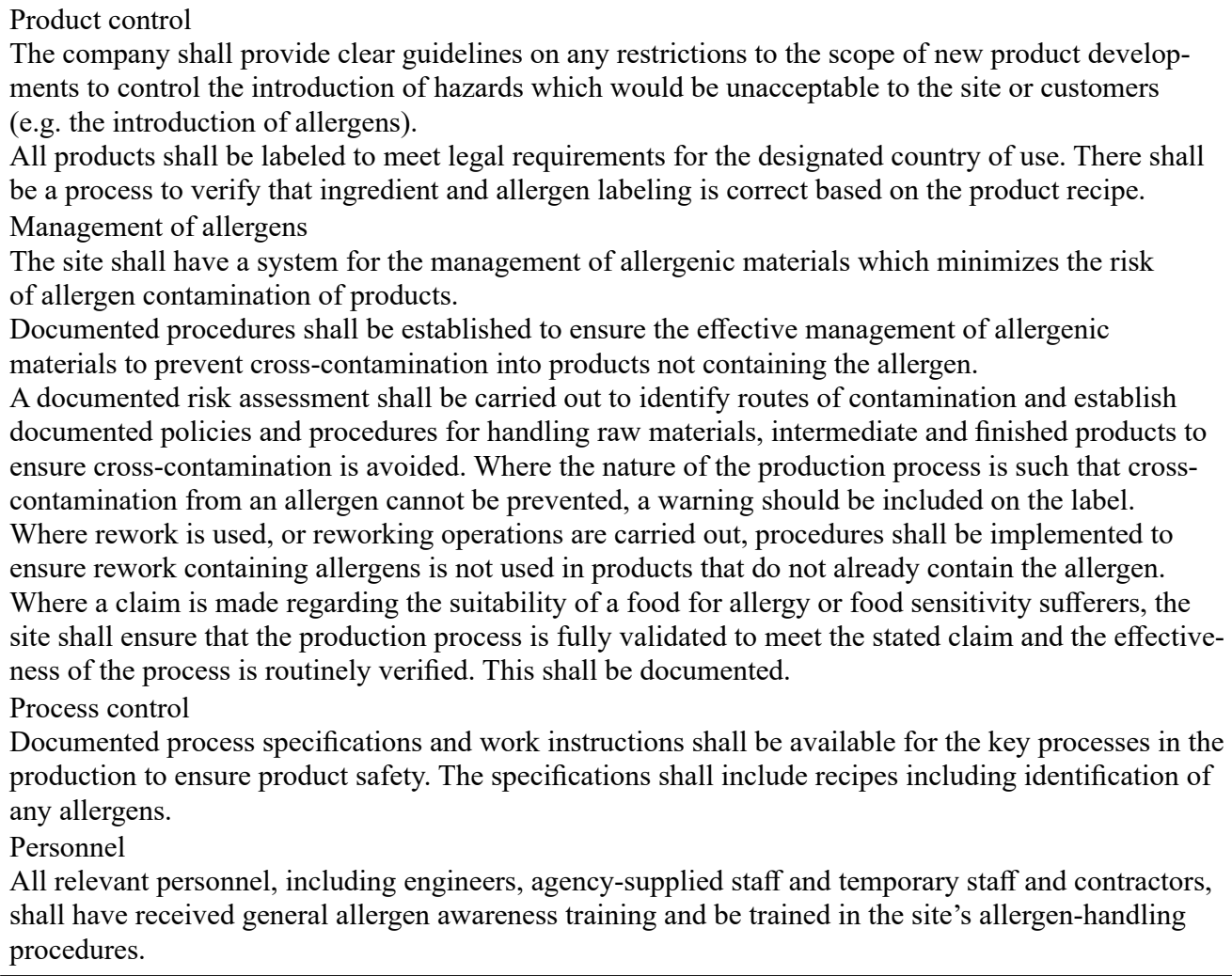 \\
\hline $\begin{array}{l}\text { IFS } \\
\text { (Version 6, 2012) }\end{array}$ & $\begin{array}{l}\text { HACCP analysis } \\
\text { The intended use of the product by the end consumer shall be described, taking into account vulnerable } \\
\text { groups of consumers (e.g. allergy sufferers). } \\
\text { Sanitary facilities, equipment for personnel hygiene and staff facilities } \\
\text { The risk of product contamination by foreign material from staff facilities shall be evaluated and } \\
\text { minimized. } \\
\text { Traceability (including GMOs and allergens) } \\
\text { A traceability system shall be in place which enables the identification of product lots and their relation } \\
\text { to batches of raw materials, packaging in direct contact with food. } \\
\text { Allergens and specific conditions of production } \\
\text { Raw material specifications identifying allergens requiring declaration shall be available. } \\
\text { The manufacturing of products which contain allergens requiring declaration shall be carried out as to } \\
\text { ensure cross-contamination is minimized as far as possible. } \\
\text { Finished products containing allergens requiring declaration shall be declared in accordance with cur- } \\
\text { rent legal requirements. For the unintentional presence, the labeling of legally declared allergens and } \\
\text { traces shall be based on hazard analysis and assessment of associated risks. } \\
\text { Where products are "free from" certain substances or ingredients causing allergies, verifiable proce- } \\
\text { dures shall be in place. }\end{array}$ \\
\hline $\begin{array}{l}\text { SQF } \\
\text { (Edition 7.2, 2014) }\end{array}$ & $\begin{array}{l}\text { Allergen management } \\
\text { A risk analysis of those raw materials, ingredients and processing aids that contain allergens shall be } \\
\text { implemented in order to develop a list of allergens. The allergen management program for food produc- } \\
\text { tion shall be documented and implemented. It shall include: identification, traceability, handling and } \\
\text { storing of products containing allergens, activities sufficient to prevent potential allergen cross contact, } \\
\text { employee training program. }\end{array}$ \\
\hline
\end{tabular}

Source: ISO 22000:2005, ISO/TS 22002-1:2009, BRC, IFS, SQF Code. 


\section{DETECTION OF ALLERGENS IN FOOD PRODUCTS}

The presence of undeclared allergenic substances in food can pose a threat to the health of allergy sufferers. Therefore, to ensure food safety, highly sensitive and reliable methods for allergen tracing and quantification in food products are required to be applied by food safety and quality inspection authorities. Methods recommended by the European Union include the enzyme-linked immunosorbent assay (ELISA) which is the most popular and commonly used methodology for the routine monitoring of allergens due to its sensitivity, high precision and good potential for standardization (Schubert-Ullrich et al., 2009; Weng et al., 2016). Two types of ELISA are the most widely used methods: Sandwich ELISA (sELISA) and Competitive ELISA (c-ELISA). The s-ELISA and c-ELISA assays were designed to detect allergens in several products: cereals, milk, eggs, shellfish, sesame, soybeans, tree nuts and peanuts (Słowianek and Leszczyńska, 2011). The major limitations of ELISA assays include matrix effects and insufficient specificity due to cross-reactivity between various substances that may produce either false positive or false negative results. Food processing is likely to cause the loss of immunological properties of allergens. Processes such as heat treatment, fermentation or hydrolysis may impact the primary structure of the protein and, as a consequence, affect the IgE-binding activity. In such cases, while the allergen quantification process may provide negative results, partially processed allergen proteins that cause an immune response in vulnerable individuals (EFSA 2014) may still be present in the food. Therefore, in order to increase the precision of allergen detection, ELISA was combined with mass spectrometry (ELISA-ICP-MS). The inductively coupled plasma mass spectrometry is a proposed method of sensitive and quantitative element-tagged immunoassay for protein analysis in biological samples (Careri et al., 2007).

Examples of rapidly developing strategies for qualitative and quantitative analyses include Lateral flow assays (LFA) and dipstick tests which are widely used as they enable performing analyses without interrupting the production process (Sajid et al., 2015). Strip assays allow the detection of allergens such as eggs $(0.02 \mathrm{mg}$ per $\mathrm{kg}$ ), gluten (10 mg per $\mathrm{kg}$ ), gliadin (2.5 mg per $\mathrm{kg}$ ), milk (below $5 \mathrm{mg}$ per $\mathrm{kg}$ ), peanuts $(1-5 \mathrm{mg}$ per $\mathrm{kg}$ ), almonds ( $1 \mathrm{mg}$ per $\mathrm{kg})$, hazelnuts $(1-5 \mathrm{mg}$ per $\mathrm{kg})$, crustaceans ( $5 \mathrm{mg}$ per $\mathrm{kg}$ ) and molluses (5 $\mathrm{mg}$ per $\mathrm{kg}$ ) (Schubert-Ullrich et al., 2009).

Food analysis relies on many other methods for allergens detection, such as rocket immunoelectrophoresis (RIE), double immunodiffusion, RAST and EAST inhibition tests, western blot, polymerase chain reaction (PCR) or liquid chromatography tandem-mass spectrometry (LC-MS-MS) (EFSA, 2014; Poms et al., 2004; Scharf et al., 2013). While some methods allow to detect and quantify even trace amounts of allergens in raw materials, intermediate or final products, their reliability still needs to be improved. The methods used in food allergen analyses will continue to evolve in line with the needs of the food industry to ensure the safety of consumers prone to allergic reactions.

\section{CONCLUSIONS}

The management of food allergens at all stages of food production and distribution processes is aimed at providing safe, high-quality products, especially in the context of the growing number of food allergies affecting the society. Measures taken by companies must be based on a detailed assessment of risks due to presence of allergens in all ingredients and additives used in the manufacturing of finished products. The probability of unintentional presence of allergens in food must be also considered. Actions taken to prevent allergen introduction into food products, and to provide consumers with reliable information on the presence or absence of allergens through adequate product labeling are vital for ensuring food safety. This problem needs to be addressed on a comprehensive basis so as not to underestimate any area of the company. Only such an approach can bring tangible benefits, including increased consumer trust in product labels, a reduction of the number of notifications on food safety hazards and, as a result, a reduction of the number of products being discontinued or withdrawn from the market.

\section{REFERENCES}

Allen, K. J., Remington, B. C., Baumert, J. L., Crevel, R., Houben, G. F., Brooke-Taylor, S., Kruizinga, A. G., Taylor, S. L. (2014). Allergen reference doses for precautionary labeling (VITAL 2.0): clinical implications. J. Allerg. Clin. Immunol., 133(1), 156-164. doi:10.1016/j.jaci.2013. 06.042 
BRC Global Standard for Food Safety (2015). Issue 7.

Careri, M., Elviri, L., Mangia, A., Mucchino, C. (2007). ICPMS as a novel detection system for quantitative elementtagged immunoassay of hidden peanut allergens in foods. Anal. Bioanal. Chem., 387(5), 1851-1854. doi:10.1007/ s00216-006-1091-0.

Dzwolak, W. (2015). Zarządzanie alergenami w produkcji środków spożywczych [Management of food allergens during production of foodstuffs]. Probl. Jakośc., 47(4), 24-28 [in Polish].

EFSA (2014). Scientific Opinion on the evaluation of allergenic foods and food ingredients for labelling purposes. Retrieved June 15th 2017 from: www.efsa.europa.eu/en/ efsajournal/pub/3894.htm

Górecka, P., Piasecka-Kwiatkowska, D., Zielińska-Dawidziak, M., Baraniak, M. (2013). Porównanie dwóch formatów metody ELISA z wykorzystaniem komercyjnie dostępnych przeciwciał do oznaczania prolamin w piwie [Comparison of two ELISA methods with commercially available antibodies for prolamin detection in beer]. Aparat. Badaw. Dydakt., 18(2), 129-133 [in Polish].

IFS (2012). Food. Standard for auditing quality and food safety of food products. Version 6.

ISO/TS 22002-1:2009. Preview. Prerequisite programmes on food safety - Part 1: Food manufacturing.

ISO 22000:2005. Food safety management systems - Requirements for any organization in the food chain.

Poms, R. E., Klein, C. L., Anklam, E. (2004). Methods for allergen analysis in food: a review. Food Add. Contam., 21(1), 1-31. doi: 10.1080/02652030310001620423.

Przybylski, W. (2016). Alergeny w mięsie - wyzwanie XXI wieku [Allergens in meat - the challenge of the 21st century]. Pol. Mięso, 4, 24-26 [in Polish].

Regulation (EU) 1169/2011 of the European Parliament and of the Council of 25 October 2011 on the provision of food information to consumers (2011). Offic. J. Eur. Union, L304/18 of 22.11.2011.

Sajid, M., Kawde, A.-N., Daud, M. (2015). Designs, formats and applications of lateral flow assay: A literature review.
J. Saudi Chem. Soc., 19(6), 689-705. doi: 10.1016/j. jscs.2014.09.001

Samoliński, B., Raciborski, F., Tomaszewska, A. (2008). Epidemiologia chorób alergicznych w Polsce [Epidemiology of allergic diseases in Poland]. Retrieved June $10^{\text {th }} 2017$ from: www.ecap.pl [in Polish].

Scharf, A., Kasel, U., Wichmann, G., Besler, M. (2013). Performance of ELISA and PCR methods for the determination of allergens in food: an evaluation of six years of proficiency testing for soy (Glycine $\max \mathrm{L}$.) and wheat gluten (Triticum aestivum L.). J. Agric. Food Chem., 61(43), 10 261-10 272. doi:10.1021/jf402619d

Schubert-Ullrich, P., Rudolf, J., Ansari, P., Galler, B., Führer, M., Molinelli, A., Baumgartner, S. (2009). Commercialized rapid immunoanalytical tests for determination of allergenic food proteins: an overview. Anal. Bioanal. Chem., 395(1), 69-81. doi: 10.1007/s00216-009-2715-y

Słowianek, M., Leszczyńska, J. (2011). Detekcja alergenów w żywności - metody immunodiagnostyczne [Dulterations detection in food industry - immunodiagnostic methods]. Przem. Spoż., 65(2), 30-32 [in Polish].

SQF Code. A HACCP-Based Supplier Assurance Code for the Food Industry (2014). Edition 7.2.

Turnbull, J. L., Adams, H. N., Gorard, D. A. (2015). Review article: the diagnosis and management of food allergy and food intolerances. Aliment. Pharmacol. Ther., 41(1), 3-25. doi: 10.1111/apt.12984

Ukleja-Sokołowska, N., Bartuzi, Z. (2015). Alergia pokarmowa - sytuacja społeczna i prawna [Food allergy - legal and social aspects]. Alerg. Astma Immunol., 20(2), 88-93 [in Polish].

Weng, X., Gaur, G., Neethirajan, S. (2016). Rapid Detection of Food Allergens by Microfluidics ELISA-Based Optical Sensor. Biosensors, 6(2), doi: 10.3390/bios6020024

Zurzolo, G. A. (2014). The Role of Precautionary Labelling for Food Allergens and the Care of Children with Food Allergies. A thesis submitted for the degree of Doctor of Philosophy. Victoria University. 